\title{
NITROGEN APPLICATION TIMING AND SOIL INORGANIC NITROGEN DYNAMICS UNDER NO-TILL OAT/MAIZE SEQUENTIAL CROPPING ${ }^{(1)}$
}

\author{
Jeferson Dieckow ${ }^{(2)}$, Egon José Meurer ${ }^{(3)} \&$ Roberto Luiz Salet $^{(4)}$
}

\begin{abstract}
SUMMARY
The timing of $\mathrm{N}$ application to maize is a key factor to be considered in no-till oat/maize sequential cropping. This study aimed to evaluate the influence of preplanting, planting and sidedress $\mathrm{N}$ application on oat residue decomposition, on soil $\mathrm{N}$ immobilisation and remineralisation and on $\mathrm{N}$ uptake by maize plants in notill oat/maize sequential cropping. Undisturbed soil cores of 10 and $20 \mathrm{~cm}$ diameter were collected from the $0-15 \mathrm{~cm}$ layer of a no-till Red Latossol, when the oat cover crop was in the milk-grain stage. Two greenhouse experiments were conducted simultaneously. Experiment A, established in the $10 \mathrm{~cm}$ diameter cores and without plant cultivation, was used to asses $\mathrm{N}$ dynamics in soil and oat residues. Experiment $B$, established in the $20 \mathrm{~cm}$ diameter cores and with maize cultivation, was used to assess plant growth and $\mathrm{N}$ uptake. An amount of $6.0 \mathrm{Mg} \mathrm{ha}^{-1}$ dry matter of oat residues was spread on the surface of the cores. A rate of $90 \mathrm{~kg} \mathrm{~N} \mathrm{ha}^{-1}$ applied as ammonium sulphate in both experiments was split in pre-planting, planting and sidedress applications as follows: (a) 00-00-00 (control), (b) 90-00-00 (pre-planting application, 20 days before planting), (c) 00-90-00 (planting application), (d) 00$30-60$ (split in a planting and a sidedress application 31 days after emergence),
\end{abstract}

\footnotetext{
(1) Part of the Master's degree thesis of the first author, submitted to the Post Graduation Program of Soil Science, Universidade Federal do Rio Grande do Sul - UFRGS. Received for publication by accepted by

(2) Professor of the Department of Soil Science and Agricultural Engeneering, Universidade Federal do Paraná - UFPR. Rua dos Funcionários 1540, CEP 80.035-050 Curitiba (PR). E-mail: jefersondieckow@ufpr.br

(3) Professor of the Department of Soil Science, Universidade Federal do Rio Grande do Sul - UFRGS. Caixa Postal 15100, CEP 90.001970 Porto Alegre (RS). Bolsista CNPq. E-mail: egon.meurer@ufrgs.br

(4) Professor of the Faculty of Agronomy, Universidade de Cruz Alta - UNICRUZ. Caixa Postal 858, CEP 98.025-810 Cruz Alta (RS). E-mail: salet@unicruz.edu.br
} 
(e) 00-00-00* (control, without oat residue) and (f) 90-00-00* (pre-planting application, without oat residue). The $\mathrm{N}$ concentration and $\mathrm{N}$ content in oat residues were not affected during decomposition by $\mathrm{N}$ fertilisation. Most of the fertiliser $\mathrm{NH}_{4}{ }^{+}-\mathrm{N}$ was converted into $\mathrm{NO}_{3}{ }^{-}-\mathrm{N}$ within 20 days after application. A significant decrease in $\mathrm{NO}_{3}^{-}-\mathrm{N}$ contents in the 0-4 cm layer was observed in all treatments between 40 and 60 days after the oat residue placement on the soil surface, suggesting the occurrence of $\mathrm{N}$ immobilisation in this period. Considering that most of the inorganic $\mathrm{N}$ was converted into $\mathrm{NO}_{3}{ }^{-}$and that no immobilisation of the pre planting fertiliser $\mathrm{N}$ occurred at the time of its application, it was possible to conclude that pre-planting applied $\mathrm{N}$ was prone to losses by leaching. On the other hand, with split $\mathrm{N}$ applications, maize plants showed $\mathrm{N}$ deficiency symptoms before sidedress application. Two indications for fertiliser-N management in no-till oat/ maize sequential cropping could be suggested: (a) in case of split application, the sidedress should be earlier than 30 days after emergence, and (b) if integral application is preferred to save field operations, this should be done at planting.

Index terms: $\mathrm{N}$ immobilisation, application timing, no-tillage, oat residue, maize.

\section{RESUMO: ÉPOCA DE APLICAÇÃO DE NITROGÊNIO E DINÂMICA DO NITROGÊEIO INORGÂNICO DO SOLO NO SISTEMA DE CULTURAS AVEIA/MILHO SOB PLANTIO DIRETO}

A época de aplicação de nitrogênio no milho é um fator chave no sistema de culturas aveia/milho. O objetivo deste estudo foi avaliar a influência da aplicação de $N$ em présemeadura, na semeadura do milho e em cobertura na decomposição de resíduos superficiais de aveia preta, na imobilização e remineralização do $N$ do solo e na absorção de $N$ pelo milho, no sistema de culturas aveia/milho em plantio direto. Colunas indeformadas de solo de 10 e $20 \mathrm{~cm}$ de diâmetro foram coletadas na camada de $0-15 \mathrm{~cm}$ de um Latossolo Vermelho, quando as plantas de aveia estavam no estádio de grão leitoso. Dois experimentos foram realizados, simultaneamente, em casa de vegetação. $O$ experimento $A$, estabelecido nas colunas de $10 \mathrm{~cm}$ de diâmetro e sem cultivo de plantas, foi usado para avaliar a dinâmica do $N$ no solo e no resíduo de aveia. O experimento $B$, estabelecido nas colunas de $20 \mathrm{~cm}$ de diâmetro e com cultivo de milho, foi usado para avaliar o crescimento de plantas e absorção de $\mathrm{N}$. Uma quantidade de $6,0 \mathrm{Mg} \mathrm{ha}^{-1}$ de resíduo de aveia preta foi colocada na superfície das colunas de solo. A dose de $90 \mathrm{~kg} N \mathrm{ha}^{-1}$, aplicada na cultura do milho na forma de sulfato de amônio, foi distribuída entre pré-semeadura, semeadura e cobertura, como se segue: (a) 00-00-00 (testemunha), (b) 90-00-00 (aplicação em pré-plantio, 20 dias antes da semeadura do milho), (c) 00-90-00 (aplicação no plantio), (d) 00-30-60 (aplicação parcelada na semeadura e cobertura 31 dias após a emergência), (e) 00-00-00* (testemunha, sem resíduo de aveia) e (f) 90-00-00* (aplicação de pré-plantio, sem resíduo de aveia). A concentração e o conteúdo de $N$ no resíduo de aveia durante sua decomposição não foram afetados pela aplicação de $\mathrm{N}$ fertilizante. A maior parte do $\mathrm{N}-\mathrm{NH}_{4}{ }^{+}$do fertilisante foi convertida em $\mathrm{N}_{-} \mathrm{NO}_{3}$ - dentro dos 20 dias após a aplicação. Uma redução significativa do conteúdo de $\mathrm{N}-\mathrm{NO}_{3}$ - da camada de $0-4 \mathrm{~cm}$ de todos os tratamentos ocorreu entre 40 e 60 dias após a colocação do resíduo de aveia na superfície das colunas de solo, indicando a ocorrência de imobilização de $N$ durante esse período. Considerando que a maior parte do Ninorgânico foi convertido em $\mathrm{N}-\mathrm{NO}_{3}$ - e que não ocorreu imobilização do $\mathrm{N}$ em pré-semeadura logo após sua aplicação, é possível concluir que o $N$ aplicado em pré-semeadura é mais vulnerável a perdas por lixiviação. Por outro lado, com a aplicação parcelada de $N$, as plantas de milho apresentaram sintomas de deficiência de $N$ antes da aplicação em cobertura. Duas indicações de manejo do $\mathrm{N}$ fertilisante no sistema aveia/milho podem ser sugeridas: (a) no caso de aplicação parcelada, a aplicação em cobertura deveria ser realizada antes dos 30 dias após a emergência, e (b) se a aplicação integral for preferida, dadas as vantagens operacionais no campo, essa deveria ser realizada durante a semeadura.

Termos de indexação: imobilização de $N$, época de aplicação, plantio direto, resíduo de aveia, milho. 


\section{INTRODUCTION}

Since the adoption of no-tillage in Southern Brazil, questions have arisen among farmers and agronomists regarding the timing of $\mathrm{N}$ fertilisation for maize cultivated subsequent to black-oat cover crop. In this grass/grass sequential cropping, $\mathrm{N}$ immobilisation induced by decomposing oat residues reduces N availability to maize (Sá, 1996; Ceretta, 1997; Pöttker \& Roman, 1998). This is especially true at the beginning of the growing season, a critical period where the crop production potential is predefined (Arnon, 1975; Fancelli \& Dourado-Neto, 1996). To overcome this problem, there have been proposals to bring the sidedress $\mathrm{N}$ application, totally or partially, forward to pre-planting (30 to 45 days before planting) or to the moment of maize planting (Sá, 1996; Ceretta, 1997). Besides increasing N availability to maize at early growth stages, this management also expedites field operations (Sá, 1996; Ceretta, 1997).

In the case of pre-planting $\mathrm{N}$ application, the maize yield varied according to precipitation during the cropping season. When the annual precipitation was near-normal, higher maize yields and $\mathrm{N}$ uptake were obtained with pre-planting than with sidedress $\mathrm{N}$ application (Basso, 1999; Basso \& Ceretta, 2000). When precipitation exceeded the normal levels (i.e., years with the "El Niño" phenomenon), grain yields and $\mathrm{N}$ uptake were significantly lower when $\mathrm{N}$ was applied at pre-planting (Basso \& Ceretta, 2000; Diekow et al., 1998), possibly due to $\mathrm{N}$ leaching losses between the time of fertiliser application and the time of effective nutrient uptake by plants. However, after simulating "El Niño" precipitations which occurred in Southern Brazil during the crop season 1997/98, Wolschick et al. (2003) did not observe reduced grain yields due to pre-planting $\mathrm{N}$ application. But in this study, the fertiliser rate applied at pre-planting (150 $\left.\mathrm{kg} \mathrm{N} \mathrm{ha}^{-1}\right)$ was higher and the period between $\mathrm{N}$ application and planting (seven days) was shorter than in the studies of Basso \& Ceretta (2000) and Diekow et al. (1998) (less than $100 \mathrm{~kg} \mathrm{~N} \mathrm{ha}^{-1}$ and more than 30 days before planting).

The answers to questions related to the effect of $\mathrm{N}$ application timing on crop yields in the no-tillage system depend mainly on a detailed understanding of $\mathrm{N}$ dynamics in the residue-soil-plant system. The effect of $\mathrm{N}$ immobilisation induced by residue decomposition was observed in a greenhouse study of Sampaio \& Salcedo (1993). Pearl millet plants grown on soils with incorporated maize straw $(\mathrm{C}: \mathrm{N}$ ratio $=38: 1)$ absorbed an $\mathrm{N}$ amount equivalent to only $20 \%$ of the $\mathrm{N}$ uptake of pearl millet plants grown in the control treatment without maize straw. When urea was applied together with straw, half of the urea-N amount was immobilised. Results of another greenhouse study (Ernani et al., 2002) suggested a higher phytomass production when maize was planted only 30 or 60 days later than when planted simultaneously with the spreading of oat residue on the soil. In this case, N immobilisation had possibly ended until the $30^{\text {th }}$ day, as previously observed by Sampaio \& Salcedo (1993).

Considering that $\mathrm{N}$ immobilisation occurs in the first 30 days after residue spreading on the soil, it would be reasonable to hypothesize, for no-till oat/ maize sequential cropping, that $\mathrm{N}$ applied at preplanting (at the same time when oat cover crop is mechanically managed) is initially immobilised, but then remineralised and available to plants later in the growing season (Sá, 1996).

The objective of this study was to investigate aspects related to oat residue decomposition, $\mathrm{N}$ immobilisation and mineralisation processes and to the $\mathrm{N}$ uptake of maize plants at early growth stages as affected by pre-planting, planting and sidedress $\mathrm{N}$ application in no-till oat/maize sequential cropping.

\section{MATERIAL AND METHODS}

Two greenhouse experiments (A and B) were carried out simultaneously. Aspects of $\mathrm{N}$ dynamics in soil and oat residues were investigated in experiment A, without maize cultivation, while aspects related to maize growth and $\mathrm{N}$ uptake were assessed in experiment B, with maize plant cultivation. Undisturbed soil cores of $10 \mathrm{~cm}$ diameter, used in experiment $\mathrm{A}$, and $20 \mathrm{~cm}$ diameter, used in experiment $\mathrm{B}$, were collected on the experimental field of Universidade de Cruz Alta, Cruz Alta (RS). The soil, under no-till management for five years, was classified as Latossolo Vermelho distrófico (distrofic Red Latossol) (Embrapa, 1999). At sampling (September 1998) the field was being cultivated with black oat cover crop (Avena strigosa Schreb.), which was then at the milk grain development stage. The soil cores were collected in-between the oat rows, with $20 \mathrm{~cm}$ high PVC cylinders that were pressed down to a depth of $15 \mathrm{~cm}$. A small pit was dug beside each cylinder to facilitate its removal.

In order to simulate the field mechanical management of oat cover crop, fresh aerial parts of oat residues were chopped into $2 \mathrm{~cm}$ fragments, homogenised and afterwards disposed on the soil cores at $6.00 \mathrm{Mg} \mathrm{ha}^{-1}$, equivalent to the dry matter amount produced in the field.

Treatments consisted of different timings of $\mathrm{N}$ application to maize and were simultaneously applied in both experiments. A rate equivalent to $90 \mathrm{~kg} \mathrm{ha}^{-1}$ of $\mathrm{N}$ was distributed among pre-planting, planting and sidedress applications as follows: (a) 00-00-00 (control, without N), (b) 90-00-00 (preplanting application, 20 days before planting), (c) 00-90-00 (planting application), (d) 00-30-60 
(split application at planting and sidedress, 31 days after emergence), (e) 00-00-00* (control, without $\mathrm{N}$ and without oat residue) and (f) 90-00-00* (preplanting application, without oat residue). Planting and emergence herein refer to planting and plant emergence observed in experiment B. For preplanting, $\mathrm{N}$ was applied on the same day as the oat residue was placed on the soil surface, simulating the field condition where $\mathrm{N}$ would be applied immediately after the mechanical oat management. To obtain the equivalent rate of $90 \mathrm{~kg} \mathrm{~N} \mathrm{ha}^{-1}$, the soil core surface area was taken into consideration. Nitrogen was applied as ammonium sulphate solution, which was slowly dripped beneath the residue layer with a pipette. The solution was prepared in a concentration respective to a precipitation of $10 \mathrm{~mm}$ to incorporate $\mathrm{N}$. Thereafter, the soil core weight was controlled daily and the soil water content maintained at approximately $70 \%$ of the water-holding capacity.

Experiment A was arranged in a randomized block design with split-split-plots ( $\mathrm{N}$ application timing in the main plots, evaluation period in subplots and soil layers in sub-sub-plots), with three replicates. The oat residue dry matter, N concentration and the soil inorganic $\mathrm{N}$ concentration were evaluated in six evaluations at 20-dayintervals. For each evaluation, the oat residue was carefully removed from the soil core surface, dried at $65{ }^{\circ} \mathrm{C}$ and ground in a knife mill. The wall of the PVC cylinder was cut to allow the removal of the soil core, which afterwards was divided into $0-4$ and 4-15 cm layers. The soil inorganic $\mathrm{N}$ concentration and the oat residue total $\mathrm{N}$ concentration were determined according to methodologies described by Tedesco et al. (1995).

Experiment B was arranged in a randomized block design, with split-plots ( $\mathrm{N}$ application timing in main plots and evaluation period in sub-plots), with three replicates. Eight maize seeds were planted in each soil core and after the emergence, which occurred six days later, only four plants were selected. At each 10-day-interval, one of these plants was harvested in order to assess the maize dry matter accumulation and $\mathrm{N}$ uptake until the $40^{\text {th }}$ day after emergence (46 days after planting). The maize tissues were analyzed for total $\mathrm{N}$ according to a methodology described by Tedesco et al. (1995).

The analysis of variance was performed according to the experimental design of each experiment. The means were compared by the Tukey test LSD $(P<0.05)$.

\section{RESULTS AND DISCUSSION}

\section{Oat residue decomposition}

The $\mathrm{N}$ fertilisation did not influence the oat residue decomposition process, since no differences were observed in dry matter, $\mathrm{N}$ concentration and $\mathrm{N}$ content of oat residue between fertilised and nonfertilised treatments during 100 days after residue placement (Figure 1). It was expected, however, that $\mathrm{N}$ fertilisation would accelerate the decomposition process, since it is commonly cited as stimulator of the soil microbial activity. This was, however, not confirmed in the current study, probably because the contact between the residue and the fertiliser was minor, since the ammonium sulphate solution was applied below the oat residue layer. Similarly, under field conditions, Ceretta et al. (2002) did not observe changes in the oat residue decomposition rate when granulated $\mathrm{N}$-fertiliser was spread over the residue, attributing such results to the aforementioned reasons.

In the period between the spreading of oat residue on the soil surface until planting, the $\mathrm{N}$ concentration and $\mathrm{N}$ content of the residue clearly diminished (Figures 1b, 1c). Inorganic N (Schreiber, 1985) and/or soluble organic $\mathrm{N}$ compounds (Cochran et al., 1980) probably leached from the oat residue during this period. From planting until 40 days later (60 days after residue placement) the mean residue $\mathrm{N}$ concentration increased from 9.5 to $11.8 \mathrm{~g} \mathrm{~N} \mathrm{~kg}^{-1}$ (Table 1 and Figure 1b), while the residue $\mathrm{N}$ content tended to stay relatively stable in this period, around 50 to $55 \mathrm{~kg} \mathrm{~N} \mathrm{ha}^{-1}$ (Figure 1c). Possibly the $\mathrm{C}$ release rate was higher than the $\mathrm{N}$ release rate in this period, reflected in a simultaneous decrease of the average C:N ratio of oat residue (Table 1). Similar results showing decreases followed by increases in the $\mathrm{N}$ concentration of wheat residue after beginning decomposition were found by Collins et al. (1990) and Schomberg \& Steiner (1999).

\section{Inorganic $\mathbf{N}$ in soil}

Twenty days after $\mathrm{N}$ application, in the preplanting as well as planting treatments, less than half of the applied $\mathrm{N}$ was in $\mathrm{NH}_{4}{ }^{+}$form (about 35$40 \mathrm{~kg} \mathrm{ha}^{-1}$ of $\mathrm{NH}_{4}{ }^{+}-\mathrm{N}$ ), while 40 days after application less than $20 \%$ was in this form (about 10-15 kg ha-1 of $\mathrm{NH}_{4}{ }^{+}-\mathrm{N}$ ) (Figure 2a). At the same time, an increase in $\mathrm{NO}_{3}-\mathrm{N}$ contents was observed (Figure 3a), reflecting the occurrence of nitrification.

Between 20 and 40 days after planting (40 and 60 days after oat residue placement), a decrease in the $\mathrm{NO}_{3}-\mathrm{N}$ content of the $0-15 \mathrm{~cm}$ layer was observed in all treatments under oat residue (Figure 3a), possibly due to a $\mathrm{N}$ immobilisation process induced by oat residue decomposition. This $\mathrm{NO}_{3}$ - depletion occurred basically in the 0-4 cm layer (Figure 3b) where the influence of the surface oat residue is supposedly higher. In the $4-15 \mathrm{~cm}$ layer underneath, no $\mathrm{N}$ depletion could be observed (Figure 3c). The decrease of the $\mathrm{NO}_{3}{ }^{-}$content in the 0-4 cm layer in the 90-00-00* treatment (Figure 3b) is attributed to leaching, supported by a corresponding increase in the $4-15 \mathrm{~cm}$ layer (Figure 3c), and not to immobilisation. 

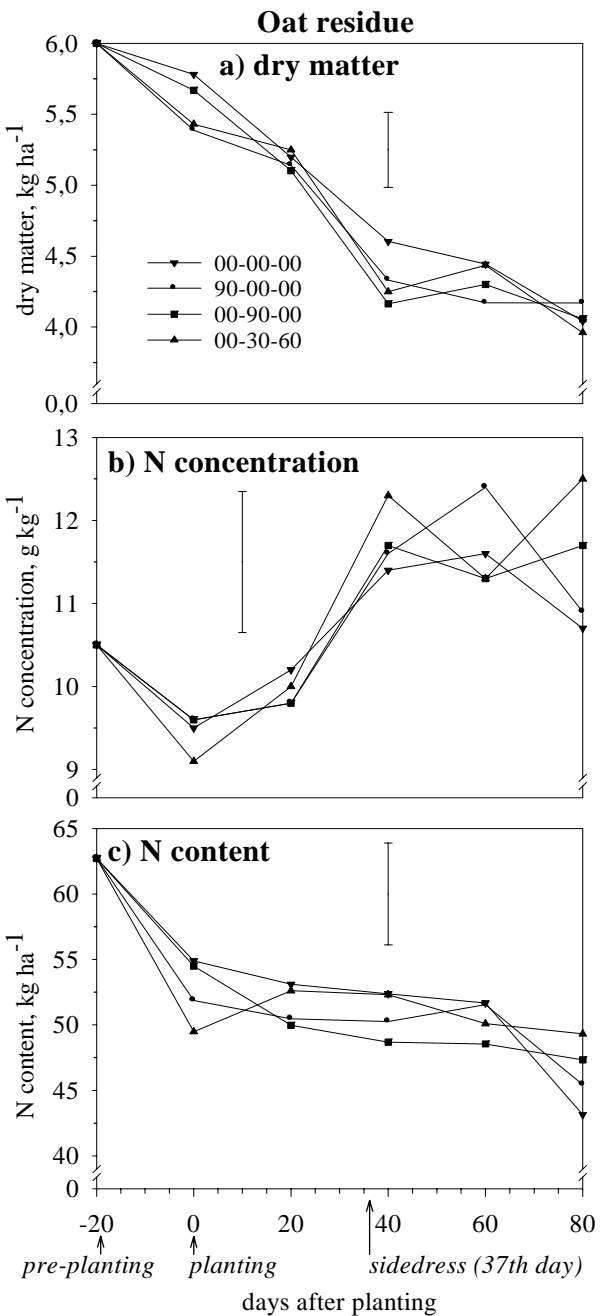

Figure 1. Amount of dry matter (a), N concentration (b) and $\mathrm{N}$ content (c) in the surface oat residue from the spreading on the soil until 80 days after planting, as affected by the timing of $\mathrm{N}$ application. 00-00-00: control; 90-00-00: $90 \mathrm{~kg} \mathrm{ha}^{-1}$ of $\mathrm{N}$ at pre-planting; 00-90-00: $90 \mathrm{~kg} \mathrm{ha}^{-1}$ of $\mathrm{N}$ at planting; 00-30-60: $30 \mathrm{~kg} \mathrm{ha}^{-1}$ of $\mathrm{N}$ at planting plus $60 \mathrm{~kg} \mathrm{ha}^{-1}$ of $\mathrm{N}$ at sidedressing. Vertical bars refer to the Tukey LSD $(P<0.05)$ within each evaluation time.

Table 1. Overall mean $N$ concentration and $C: N$ ratio of oat residue of the treatments during the experimental period

\begin{tabular}{ccc}
\hline Time & N & C:N ratio \\
\hline days after planting & $\mathrm{g} \mathrm{kg}^{-1}$ & \\
-20 & 10,5 & 38 \\
0 & 9,5 & 42 \\
20 & 10,0 & 40 \\
40 & 11,8 & 34 \\
60 & 11,7 & 34 \\
80 & 11,5 & 35 \\
\hline
\end{tabular}
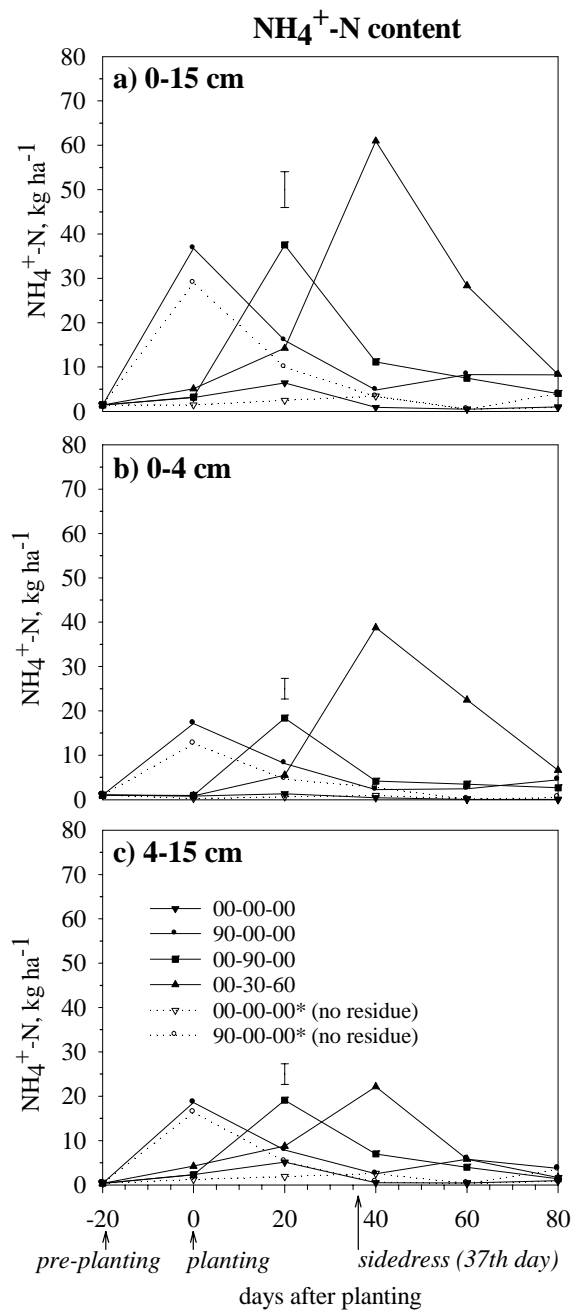

Figure 2. Soil $\mathrm{NH}_{4}{ }^{+}-\mathrm{N}$ content in the $0-15 \mathrm{~cm}$ layer (a), 0-4 cm layer (b) and 4-15 cm layer (c) from 20 days before until 80 days after maize planting, as affected by the timing of $\mathrm{N}$ application. 00-00-00: control; 90-00-00: $90 \mathrm{~kg} \mathrm{ha}^{-1}$ of $\mathrm{N}$ at pre-planting; 00-90-00: $90 \mathrm{~kg} \mathrm{ha}^{-1}$ of $\mathrm{N}$ at planting; 00-30-60: $30 \mathrm{~kg} \mathrm{ha}^{-1}$ of $\mathrm{N}$ at planting plus $60 \mathrm{~kg} \mathrm{ha}^{-1}$ of $\mathrm{N}$ at sidedressing. Vertical bars refer to the Tukey LSD $(P<0.05)$ of each evaluation.

An intriguing question is therefore: why would such $\mathrm{N}$ immobilisation have occurred in the period of 20 to 40 days after planting (40 to 60 days after residue placement) only, and not immediately after or within 30 days after residue application, as reported in other greenhouse studies (Sampaio \& Salcedo, 1993; Ernani et al., 2002)? Before giving any explanation, it is worth mentioning that when residue is placed on the soil surface, organic $\mathrm{C}$ (substrate) can reach soil microorganisms through a partial residue incorporation via rainfall (Shields \& Paul, 1973) and/ or through leaching of soluble organic compounds from residues into the soil surface layer, also by rainfall or irrigation water (Cochran et al., 1980). 

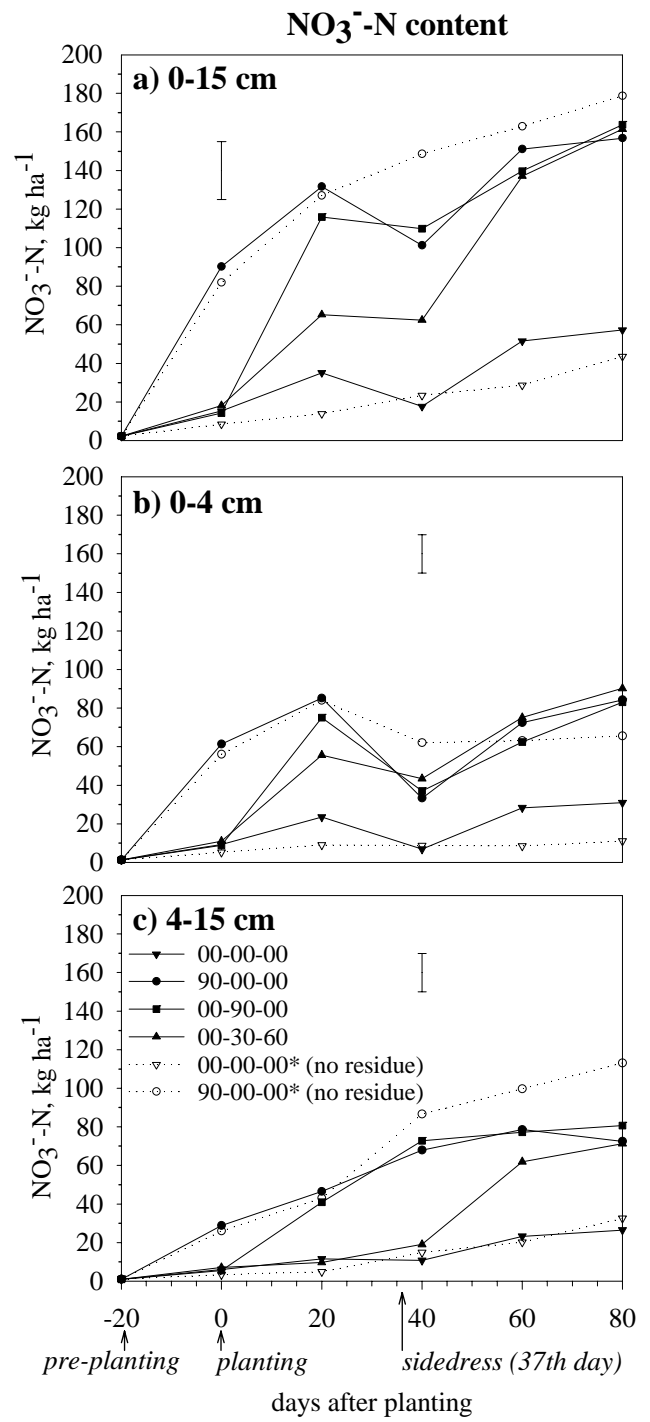

Figure 3. Soil $\mathrm{NO}_{3}^{-}-\mathrm{N}$ content in the $0-15 \mathrm{~cm}$ layer (a), 0-4 cm layer (b) and 4-15 cm layer (c) from 20 days before until 80 days after maize planting, as affected by the timing of $\mathrm{N}$ application. 00-00-00: control; 90-00-00: $90 \mathrm{~kg} \mathrm{ha}^{-1}$ of $\mathrm{N}$ at pre-planting; 00-90-00: $90 \mathrm{~kg} \mathrm{ha}^{-1}$ of $\mathrm{N}$ at planting; 00-30-60: $30 \mathrm{~kg} \mathrm{ha}^{-1}$ of $\mathrm{N}$ at planting plus $60 \mathrm{~kg} \mathrm{ha}^{-1}$ of $\mathrm{N}$ at sidedressing. Vertical bars refer to the Tukey LSD $(P<0.05)$ of each evaluation.

Since residues were not soil-incorporated and the soil-residue contact was restricted to the surfaceresidue interface only, one can infer that residue incorporation was not the way $\mathrm{C}$ reached microorganisms. Therefore, probably in the period of 20-40 days after planting, a kind of flush of soluble organic compounds, of high C:N ratio, had leached into the $0-4 \mathrm{~cm}$ layer, inducing $\mathrm{NO}_{3}^{-}-\mathrm{N}$ immobilisation. A nitrogen immobilisation peak after ammonium sulphate application was also observed in a Cerrado Latossol, though 20 days after application (Lara-Cabezas, 2001).
The supposition that organic compounds had leached from oat residues is reinforced by studies of Cochran et al. (1980) and Elliott et al. (1981). The former observed soluble $\mathrm{C}$ leaching from wheat residue during an incubation period of nine weeks. In the first weeks of incubation, the $\mathrm{C}: \mathrm{N}$ ratio of the leached solution was lower than 20:1, while in the fifth week it was 60:1, therefore increasing the $\mathrm{N}$ immobilisation potential in soil.

Increments in the amount of inorganic $\mathrm{N}$ in the $0-4 \mathrm{~cm}$ layer occurred in the period of 40 to 60 days after planting, evidencing the subsequent $\mathrm{N}$ remineralisation process (Figure $3 \mathrm{~b}$ ). The span of both immobilisation and subsequent remineralisation (40 days) was shorter compared to that found in a study by Mary et al. (1996), where only remineralisation extended over a period of 40 days. This may reflect a higher assimilation of the leached organic compounds by soil microorganisms. The $\mathrm{N}$ remineralisation afterwards was as rapid as the microbial attack on the substrate.

In the $4-15 \mathrm{~cm}$ layer, the $\mathrm{NO}_{3}{ }^{-} \mathrm{N}$ content increased (Figure 3c), mainly because of $\mathrm{NO}_{3}-\mathrm{N}$ leaching from the surface layer and fertiliser-N nitrification. The $\mathrm{NO}_{3}-\mathrm{N}$ Content Never Decreased In This Layer, Which Means That No Net Immobilisation Occurred There. Net Nimmobilisation occurred only in the 0-4 cm layer (Figure 3b), which was most influenced by compounds leached out from oat residue. This would corroborate the suggestion that to avoid $\mathrm{N}$ deficiencies due to net immobilisation in soils managed under no-tillage, fertiliser- $\mathrm{N}$ should be applied below the "immobilisation surface layer", 3 to $6 \mathrm{~cm}$ below soil surface (Cochran et al., 1980; Mengel et al., 1982; Salet et al., 1997).

Considering that 20 days after pre-planting application, half of the inorganic $\mathrm{N}$ was in $\mathrm{NO}_{3}{ }^{-}$form and that no immobilisation of fertiliser $\mathrm{N}$ occurred simultaneously with oat residue placement on soil surface, it is possible to conclude that this $\mathrm{N}$ applied before planting tends to get lost through leaching. This is particularly relevant in years of excessive precipitation, as "El Niño" years, and explains why in such years maize grain yields are lower when $\mathrm{N}$ is applied before planting (Basso \& Ceretta, 2000; Pöttker \& Wiethölter, 2000). This management practice should therefore be considered risky.

\section{Dry matter and $\mathrm{N}$ accumulation in the shoot of maize plants}

The increments in dry matter accumulation due to $\mathrm{N}$ fertilisation were only observed from the $26^{\text {th }}$ day after planting (20 days after emergence) onwards (Figure $4 a$ ). On the $36^{\text {th }}$ day after planting (30 days after emergence) a higher dry matter accumulation was observed in the treatments 90 00-00 and 00-90-00 compared to that in the splitapplication treatment (00-30-60). Although not significant, this difference tended to appear 46 days 
after planting (nine days after sidedress application) as well. When $\mathrm{N}$ was split-applied, the plants presented typical $\mathrm{N}$ deficiency symptoms during the period before sidedress application (26 to 36 days after planting) as well as lower dry mass accumulation than pre-planting and planting applications 36 days after planting (Figure 4a). This might suggest that sidedress application 31 days after emergence was too late and that it would be reasonable to apply sidedress fertilisation at an earlier stage.
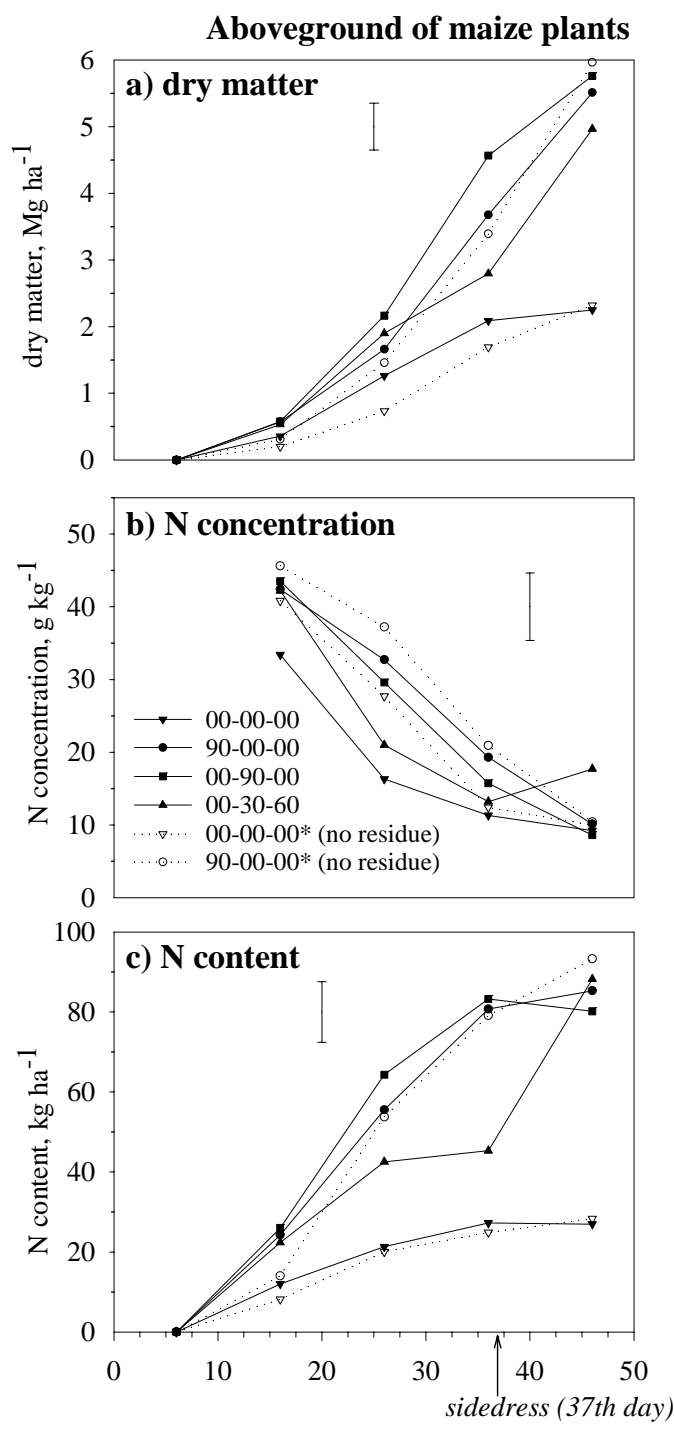

days after planting

Figure 4. Amount of dry matter (a), $\mathrm{N}$ concentration (b) and $N$ content (c) in aerial part of maize plants, as affected by the timing of $\mathrm{N}$ application. 00-00-00: control; 90-00-00: $90 \mathrm{~kg} \mathrm{ha}^{-1}$ of $\mathrm{N}$ at pre-planting; 00-90-00: $90 \mathrm{~kg} \mathrm{ha}^{-1}$ of $\mathrm{N}$ at planting; 00-30-60: $30 \mathrm{~kg} \mathrm{~N}$ $\mathrm{ha}^{-1}$ at planting plus $60 \mathrm{~kg} \mathrm{ha}^{-1}$ of $\mathrm{N}$ at sidedressing. Vertical bars refer to the Tukey LSD $(P<0.05)$ of each evaluation.
The $\mathrm{N}$ concentration in the tissue of the aerial part decreased along with the plant development (Figure $4 \mathrm{~b}$ ). The accumulation rate of photosynthesized organic compounds is higher than the $\mathrm{N}$ uptake rate, so this element is diluted in the plant tissues. The $\mathrm{N}$ accumulation in plants under split $\mathrm{N}$ application during the 26-36 days after planting was lower than in plants treated with preplanting and planting $\mathrm{N}$ application (Figure 4c). This is in accordance with the $\mathrm{N}$ availability in soil (Figure 5). However, after sidedress application, N accumulation was equal in all fertilised treatments.

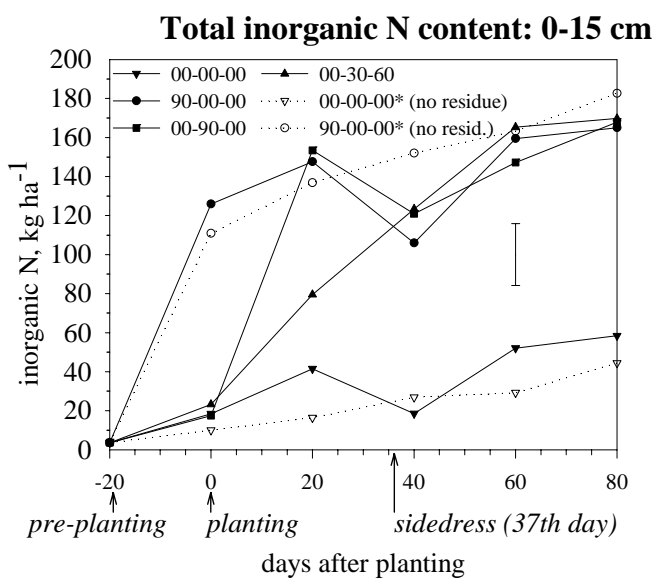

Figure 5. Soil total inorganic $\mathrm{N}$ content in the 0 $15 \mathrm{~cm}$ layer from 20 days before until 80 days after maize planting, as affected by the timing $\mathrm{N}$ application. 00-00-00: control; 90-00-00: $90 \mathrm{~kg} \mathrm{ha} \mathrm{a}^{-1}$ of $\mathrm{N}$ at pre-planting; 00-90-00: $90 \mathrm{~kg} \mathrm{ha}^{-1}$ of $\mathrm{N}$ at planting; 00-30-60: $30 \mathrm{~kg} \mathrm{ha}^{-1}$ of $\mathrm{N}$ at planting plus $60 \mathrm{~kg} \mathrm{ha}^{-1}$ of $\mathrm{N}$ at sidedressing. Vertical bars refer to the Tukey LSD $(P<0.05)$ of each evaluation.

\section{CONCLUSIONS}

1. Considering the higher risks of $\mathrm{N}$ losses by leaching with pre-planting $\mathrm{N}$ application and the possibility of $\mathrm{N}$ deficiency when sidedress fertilisation is applied 30 days after emergence or even later, two indications for fertiliser-N management in no-till oat/maize sequential cropping could be suggested: (a) in case of split application, the sidedress fertilisation should be applied earlier than 30 days after maize emergence, and (b) if integral application is preferred to expedite field operations, this should be done at planting, taking the appropriate distance between fertiliser and seeds into account to avoid salt injuries in the latter.

2. However, it is important to emphasise the importance of additional field experiments to further support the findings of this study since variations in soil and climatic conditions must also be taken into consideration when recommending $\mathrm{N}$ fertilization. 


\section{ACKNOWLEDGEMENTS}

The authors thankfully acknowledge the master thesis scholarship and the research scholarship awarded by the CNPq to J. Dieckow and E.J. Meurer, respectively, Professor Clóvis da Ros (UNICRUZ) for his valuable suggestions and for allowing soil sampling on the experimental field; and José F. da Silva for his helpful collaboration in the greenhouse activities.

\section{CITED LITERATURE}

ARNON, I. Mineral nutrition of maize. Bern, International Potash Institute, 1975. 452p.

BASSO, C. Épocas de aplicação de nitrogênio para o milho cultivado em sucessão a plantas de cobertura de solo, no sistema plantio direto. Santa Maria, UFSM, Centro de Ciências Rurais, 1999. 91p. (Tese de Mestrado)

BASSO, C.J. \& CERETTA, C.A. Manejo do nitrogênio no milho em sucessão a plantas de cobertura de solo, sob plantio direto. R. Bras. Ci. Solo, 34:905-915, 2000.

CERETTA, C.A. Manejo da adubação nitrogenada na sucessão aveia/milho, no sistema plantio direto. In: FRIES, M.R.; DALMOLIN, R.S.D., coord. Atualização em recomendação de adubação e calagem. Santa Maria, Pallotti, 1997. p.112124 .

CERETTA, C.A.; BASSO, C.J.; FLECHA, A.M.T; PAVINATO, P.S.; VIERIA, F.C.B. \& MAI, M.E.M. Manejo da adubação nitrogenada na sucessão aveia preta/milho, no sistema plantio direto. R. Bras. Ci. Solo, 26:163-171, 2002.

COCHRAN, V.L.; ELLIOTT, L.F. \& PAPENDICK, R.I. Carbon and nitrogen movement from surface-applied wheat (Triticum aestivum) straw. Soil Sci. Soc. Am. J., 44:978982, 1980.

COLLINS, H.P.; ELLIOTT, L.F. \& PAPENDICK, R.I. Wheat straw decomposition and changes in decomposability during fields exposure. Soil Sci. Soc. Am. J., 54:1013-1016, 1990.

DIEKOW, J.; CERETTA, C.A. \& PAVINATO, P. É possível antecipar a adubação nitrogenada do milho no sistema plantio direto? In: REUNIÃO SUL-BRASILEIRA DE CIÊNCIA DO SOLO, 2., Santa Maria, DS/UFSM, 1998. p.163-166.

ELLIOTT, L.F.; COCHRAN, V.L. \& PAPENDICK, R.I. Wheat residue and nitrogen placement effects on wheat growth in the greenhouse. Soil Sci., 131:48-52, 1981.

EMPRESA BRASILEIRA DE PESQUISA AGROPECUÁRIA EMBRAPA. Sistema Brasileiro de Classificação de Solos. Rio de Janeiro, 1999. 412p.
ERNANI, P.R.; SANGOI, L. \& RAMPAZZO, C. Lixiviação e imobilização de nitrogênio num Nitossolo como variáveis da forma de aplicação da uréia e da palha de aveia. R. Bras. Ci. Solo, 26:993-1000, 2002.

FANCELLI, A.L. \& DOURADO-NETO, D. Cultura do milho: aspectos fisiológicos e manejo da água. Inf. Agron., 73:1-4, 1996.

LARA-CABEZAS, W.A.R. Imobilização do nitrogênio na cultura do milho após a aplicação em pré e pós-semeadura da uréia e sulfato de amônio. R. Plan. Direto, n65:14-20, 2001.

MARY, B.; RECOUS, S.; DARWIS, D. \& ROBIN, D. Interactions between decomposition of plants residues and nitrogen cycling in soil. Plant Soil, 181:71-82, 1996.

MENGEL, D.B.; NELSON, D.W. \& HUBER, D.M. Placement of nitrogen fertilizer for no-till and conventional till corn. Agron. J., 74:515-518, 1982.

PÖTTKER, D. \& ROMAN, E.S. Efeito do nitrogênio em trigo cultivado após diferentes sucessões de culturas. Pesq. Agrop. Bras., 33:501-507, 1998.

PÖTTKER, D. \& WIETHÖLTER, S. Antecipação da aplicação de nitrogênio em milho. In: FERTBIO 2000, Santa Maria, 2000. Resumos. Santa Maria, Laboratório de Geomática, 2000. CD ROOM

SÁ, J.C.M. Manejo de nitrogênio na cultura de milho no sistema plantio direto. Passo Fundo, Aldeia Norte, 1996. 23p.

SALET, R.L.; VARGAS, L.K.; ANGHINONI, I.; KOCHHANN R.A.; DENARDIN, J.E. \& CONTE, E. Porque a disponibilidade de nitrogênio é menor no sistema plantio direto? In: SEMINÁRIO INTERNACIONAL DO SISTEMA PLANTIO DIRETO, 2., Passo Fundo, 1997. Anais. Passo Fundo, Embrapa-Cnpt, 1997, p.217-219.

SAMPAIO, E.V.S.B. \& SALCEDO, I.H. Mineralização e absorção por milheto do nitrogênio do solo, da palha de milho- $\left({ }^{15} \mathrm{~N}\right)$ e da uréia- $\left({ }^{15} \mathrm{~N}\right)$. R. Bras. Ci. Solo, 17:423-429, 1993.

SCHOMBERG, H.H. \& STEINER, J.L. Nutrient dynamics of crop residues decomposing on a fallow no-till soil surface. Soil Sci. Soc. Am. J., 63:607-613, 1999.

SCHREIBER, J.D. Leaching of nitrogen, phosphorus, and organic carbon from wheat straw residues: II Loading rate. J Environ. Qual., 14:256-260, 1985.

SHILDS, J.A. \& PAUL, E.A. Decomposition of ${ }^{14}$ C-labelled plant material under field conditions. Can. J. Soil Sci., 53:297306, 1973

TEDESCO, M.J.; GIANELLO, C.; BISSANI, C.A.; BOHNEN, H. \& VOLKWEISS, S.J. Análise de solo, plantas e outros materiais. 2.ed. Porto Alegre, Universidade Federal do Rio Grande do Sul, 1995. 174p. (Boletim Técnico, 5)

WOLSCHICK, D.; CARLESSO, R.; PETRY, M.T.; JADOSKI, S.O. Adubação nitrogenada na cultura do milho no sistema plantio direto em ano com precipitação pluvial normal e com “El Niño". R. Bras. Ci. Solo, 27:461-468, 2003. 